\title{
How did the UK government face the global COVID-19
}

pandemic?

Tamiris Cristhina Resende ${ }^{12}$

Marco Antonio Catussi Paschoalotto ${ }^{3}$

Stephen Peckham ${ }^{1} 4$

Claudia Souza Passador ${ }^{5}$

João Luiz Passador ${ }^{5}$

1 University of Kent / Centre for Health Services Studies, Canterbury - United Kingdom

2 Universidade Federal do Rio Grande do Norte, Natal / RN - Brazil

3 Universidade do Oeste Paulista / Business School, Presidente Prudente / SP - Brazil

${ }^{4}$ London School of Hygiene and Tropical Medicine / Department of Public Health and Policy, London - United Kingdom

${ }^{5}$ Universidade de São Paulo, Ribeirão Preto / SP - Brazil

This paper aims to analyse the coordination and cooperation in Primary Health Care (PHC) measures adopted by the British government against the spread of the COVID-19. PHC is clearly part of the solution founded by governments across the world to fight against the spread of the virus. Data analysis was performed based on coordination, cooperation, and PHC literature crossed with documentary analysis of the situation reports released by the World Health Organisation and documents, guides, speeches and action plans on the official UK government website. The measures adopted by the United Kingdom were analysed in four periods, which helps to explain the courses of action during the pandemic: pre-first case (January 22- January 31, 2020), developing prevention measures (February 1 -February 29, 2020), first Action Plan (March 1- March 23, 2020) and lockdown (March 24-May 6, 2020). Despite the lack of consensus in essential matters such as Brexit, the nations in the United Kingdom are working together with a high level of cooperation and coordination in decision-making during the COVID-19 pandemic.

Keywords: COVID-19; coordination and cooperation; United Kingdom; primary health care; public health.

\section{Como o governo do Reino Unido enfrentou a pandemia global da COVID-19?}

Este artigo tem o objetivo de analisar a coordenação e cooperação nas medidas de atenção básica à saúde adotadas pelo governo britânico no combate a evolução da COVID-19. A atenção básica à saúde é parte da solução adotada pelos governos no mundo para combater o vírus. Foi utilizada da análise de dados baseada na literatura de coordenação, cooperação e atenção básica à saúde, de forma cruzada com a análise documental dos relatórios elaborados pela Organização Mundial da Saúde e documentos, guias, discursos e planos de ação nos sites oficiais do governo britânico. As medidas adotadas pelo governo britânico foram analisadas em 4 períodos, de forma a ajudar na explicação das ações durante a pandemia: pré-primeiro caso (22 a 31 de janeiro), desenvolvendo medidas de prevenção (01 a 29 de fevereiro), primeiro plano de ação (1 a 23 de março) e lockdown (24 de março a 6 de maio). Apesar da falta de consenso em temas essenciais como o Brexit, as nações no Reino Unido estão trabalhando juntas com um alto nível de cooperação e coordenação na tomada de decisão durante o surto do coronavírus. Palauras-chave: COVID-19; coordenação e cooperação; Reino Unido; atenção básica à saúde; saúde pública. 


\section{¿Cómo hizo frente el gobierno del Reino Unido a la pandemia mundial de COVID-19?}

Este artículo tiene como objetivo analizar la coordinación y cooperación en las medidas de atención primaria de salud adoptadas por el gobierno británico para combatir la evolución de la COVID-19. Una crisis sin precedentes exige soluciones de políticas públicas y una gobernanza única en el desafío más importante del siglo XXI. La atención primaria de salud es claramente parte de la solución adoptada por los gobiernos de todo el mundo para combatir el virus. Se utilizó el análisis de datos -basado en la literatura sobre coordinación, cooperación y atención primaria de salud- cruzado con el análisis documental de informes elaborados por la Organización Mundial de la Salud y documentos, guías, discursos y planes de acción de los sitios web oficiales del gobierno británico. Las medidas adoptadas por el gobierno británico se analizaron en 4 periodos con el fin de ayudar a explicar las acciones durante la pandemia: pre-primer caso ( 22 a 31 de enero), desarrollo de medidas preventivas (01 a 29 de febrero), primer plan de acción (01 a 23 de marzo) y confinamiento (24 de marzo a 6 de mayo). A pesar de la disparidad en el consenso sobre temas clave como el Brexit, las naciones del Reino Unido están trabajando juntas con un alto nivel de cooperación y coordinación en la toma de decisiones durante el brote de coronavirus.

Palabras clave: COVID-19; coordinación y cooperación; Reino Unido; primeros auxilios; salud pública.

\section{ACKNOWLEDGEMENTS}

We would like to thank the Centre for Health Services Studies (CHSS) at the University of Kent, the National Council for the Improvement of Higher Education (CAPES), the National Council for Scientific and Technological Development (CNPq) and the Institute of Advanced Studies at the University of São Paulo (Ribeirão Preto).

\section{INTRODUCTION}

The Coronavirus Disease 2019 (COVID-19) is an unexpected challenge faced by both developed and in developing economies. The disease first discovered in December 2019 in China (Chen et al., 2020) spread to the whole world, making Europe the epicentre of the outbreak in the first months of 2020. The World Health Organization (WHO) declared on March 12th the situation as a Global Pandemic which means that the virus is widely disseminated (WHO, 2020).

As of May 4th, 2020, 3.519.901 people tested positive for COVID-19 in the World (Johns Hopkins University, 2020). United States, Italy, United Kingdom, Spain and France are the countries with the highest number of cases, and the United Kingdom is in the $4^{\text {th }}$ position in this list (Johns Hopkins University, 2020). The United States has the largest number of fatalities with 57.511 by May $4^{\text {th }}$ (Johns Hopkins University, 2020).

This global pandemic also demonstrates how different country's economic and social systems are interconnected. An unprecedented crisis is demanding public policy solutions and an original governance structure. Intersectoral public policies and coordinated efforts between the different government agencies are part of the solution to economic, social and population health recovery.

The health systems of countries such as Italy, Spain and parts of the USA have been close to collapse due to the overwhelming number of cases of people with COVID-19 and the lack of physical and personnel capacity and organisational structure to meet the sudden increase in demand. In the UK, initially, the national response to the pandemic was slow, with an NHS not overwhelmed and maintaining spare capacity in ICUs. Suddenly, the volume of infected people increased, and a new 
"Nightingale Hospital" was constructed in London to take up to 4,000 COVID patients, while other cities have remained virtually unused. London was first place where a Nightingale hospital was introduced due the fact where most cases were initially. However, overall the NHS coped by drastically reducing all other activity and the Nightingale hospitals remain white elephants.

A key point to understand cooperation and coordination in UK is that response in the UK had been centrally led - with differences for the four constituent countries demonstrating increasing divergenece of practice (especially about moving from lockdown). In England the central response has had problems - not so apparent in the smaller countries.

Primary Health Care (PHC) is part of the solution in the fight against the virus spreading but also central to maintaining regular health care services. The general practice provides the majority of first-contact care in the UK and has rapidly had to change the way it delivers care as a result of the pandemic. For example, about three-quarters of consultations are undertaken by phone or video link - some three times as many as before the epidemic.

Therefore, the objective of this paper is to analyse how the British government has responded to the Coronavirus disease 2019 (COVID-19) outbreak emphasising the coordination and cooperation process into the adopted measures to avoid the spreading of the virus. We analyse the strategies and actions of the UK government focusing primarily on England.

Understanding the measures adopted by the countries to face the COVID-19 is valuable to understand what approaches to coordination, structures of governance and velocity of response might be most effective. Successful implementation of strategies to reduce health care facility use will be a crucial determinant for success and can be the key to economic and social recovery. Also, the paper is not exhausting the elements which could be responsible for success or failure into COVID-19 countries' response, as political or institutional factors.

\section{LITERATURE REVIEW: COORDINATION, COOPERATION AND PRIMARY HEALTH CARE (PHC)}

The coordination and cooperation process is about to identify the most important and influent actors over the policy, how they connect themselves at the moment using formal or informal structures and, how they could collaborate to solve the problem (Giljević \& Lalić Novak, 2018; Hämäläinen et al., 2016; Woods \& Bowman, 2018). To support the coordination process between the countries, in some cases, non-governmental organisations (NGO) assume this responsibility with macro strategies to share knowledge and information, as WHO (Gänzle, Stead, Sielker \& Chilla, 2019). These macro strategies are responsible for guiding the common objectives in the area (health) and establishing directives to execute the same response to the problem (Gänzle et al., 2019; Westerink et al., 2017).

In the health area, scientific knowledge is crucial to develop new vaccines and medical procedures to fight against new virus and diseases, as in this COVID-19 outbreak (Egger, 2017; Hämäläinen et al., 2016). Also, some elements can influence and impact the cooperation and collaboration activity, as the coalition's ability, the cross-sector integration, the government structure and functionality, the countries' economic power, the trust in the organisation and, supranational legislation (Aamodt, 2018; Fathalikhani, Hafezalkotob \& Soltani, 2020; Lavenex, 2009; Lidén, Nyhlén \& Nyhlén, 2015).

Although, collaboration and coordination between institutions are not "one-way road" to accomplish the strategies, because of the different used approaches as non-formal cooperation and 
competitiveness (Egger, 2017; Gänzle et al., 2019). At this moment, the subnational contribution is fundamental to transform the international and national directives on delivered services (Woods \& Bowman, 2018).

Therefore, in the COVID-19 crisis, it is necessary to actively look to the international, national and subnational level of cooperation and coordination, per passing by WHO, Ministries of Health, Secretaries of Health, Health agencies and, all the subnational structures (Lidén et al., 2015; Hämäläinen et al., 2016).

The United Kingdom has one of the biggest publicly funded and organised health systems in the world. The National Health System (NHS) in England cover acurate primary health care and includes 35,000 general practitioners, 17,000 nurses, 14,000 other staff involved in direct patient care and nearly 70,000 administrative and support staff (NHS Digital March 2020) such as physiotherapy, pharmacy, counselling services across the UK organised in over 10,000 practice units (national level). This amount of staff is bigger considering Wales, Scotland and North Ireland.

The British National Health Service (NHS) is primary care led system with general practitioners (GPs) being the first point of contact for citizens with non-emergency health care needs (subnational level). GPs have traditionally worked in practices, led by partners (or a sole partner), employing a team of staff (nurses, care assistants, receptionists, managers) and liaising with other community services. They coordinate care for local people who register with their practice (local level). The World Health Organization (2018, p. 5) states in the Astana Declaration that the "strengthening primary health care (PHC) is the most inclusive, effective and efficient approach to enhance people's physical and mental health, as well as social well-being and that PHC is a cornerstone of a sustainable health system" (international level). WHO also mention that the PHC is relevant for the health-related Sustainable Development Goals (WHO, 2018).

General practice is contracted to provide services to the NHS and this funding consisting of core funding based on patient registration with some additional fee-for-service, infrastructure and quality payments (Quality and Outcomes Framework [QOF]). The sector is currently facing financial and other pressures that have threatened patient experience. Increases in the number of older people, more lifestyle-related conditions, rising expectations and transfer of some tasks previously undertaken in hospitals to primary care have added significantly to the general practice workload. Simultaneously, recruitment and retention problems have reduced the number of GPs per capita (Fletcher et al., 2017), and shortages of primary and community nurses have exacerbated staffing problems (Baird, Charles, Honeyman, Maguire \& Das, 2016; NHS England, 2016; Primary Care Workforce Commission, 2017).

Still, there are remain considerable pressures on general practice, and it is vital to explore whether this contributed to the United Kingdom not being as prepared to deal with a massive disease outbreak, like the one imposed by COVID-19, as might have been expected for a country with a comprehensive health system. The COVID-19 mechanism of transmission remains unknown (Phan, 2020), and that's why prevention measures using PHC is relevant to contain the number of cases.

Therefore, the UK's COVID-19 response shows the cooperation and coordination in the health care area through the understanding of international communication (WHO), absorbing and making decisions nationally (UK), and attending to the demand with subnational and local structure (British government and GPs). 


\section{RESEARCH DESIGN AND METHODS}

To ensure a comprehensive inclusion of available literature on Coordination and Primary Health Care (PHC), we consulted several sources, including the Lancet, Medline, Web of Science and PubMed. By asking experts, we sought to identify governmental documents describing the measures adopted in the United Kingdom against the COVID-19 outbreak.

We also analysed the guidelines documents from the World Health Organization, such as the diary Situation Reports published in https://www.who.int/emergencies/diseases/novel-coronavirus-2019/ situation-reports. The Coronavirus COVID-19 Global Cases by the Center for Systems Science and Engineering (CSSE) at Johns Hopkins University Map is also an essential source of information in this article.

The documental analysis we carried out in the https://gov.uk website in the Coronavirus section where we analysed all the content in the section "All Coronavirus (COVID-19) information". Hence, we have analysed 499 news, Prime Minister speeches, communication and guidance published until May 6. The following keywords guided the analysis: measures, coordination, councils, General Practices and Primary Health Care.

\section{RESULTS AND DISCUSSION}

The measures adopted by the United Kingdom were analysed in four periods of time which helps to explain the courses of action during the pandemic: pre-first case (January 22-January 31), developing prevention measures (February $1^{\text {st }}$-February 29), first Action Plan (March $1^{\text {st }}$-March 23) and lockdown (March 24-May 6). The figure presents the main government actions in parallel with COVID-19 cases and deaths:

FIGURE 1 SYNTHETIC HISTORY OF GOVERNMENT ACTIONS X CORONAVIRUS CASES/DEATHS

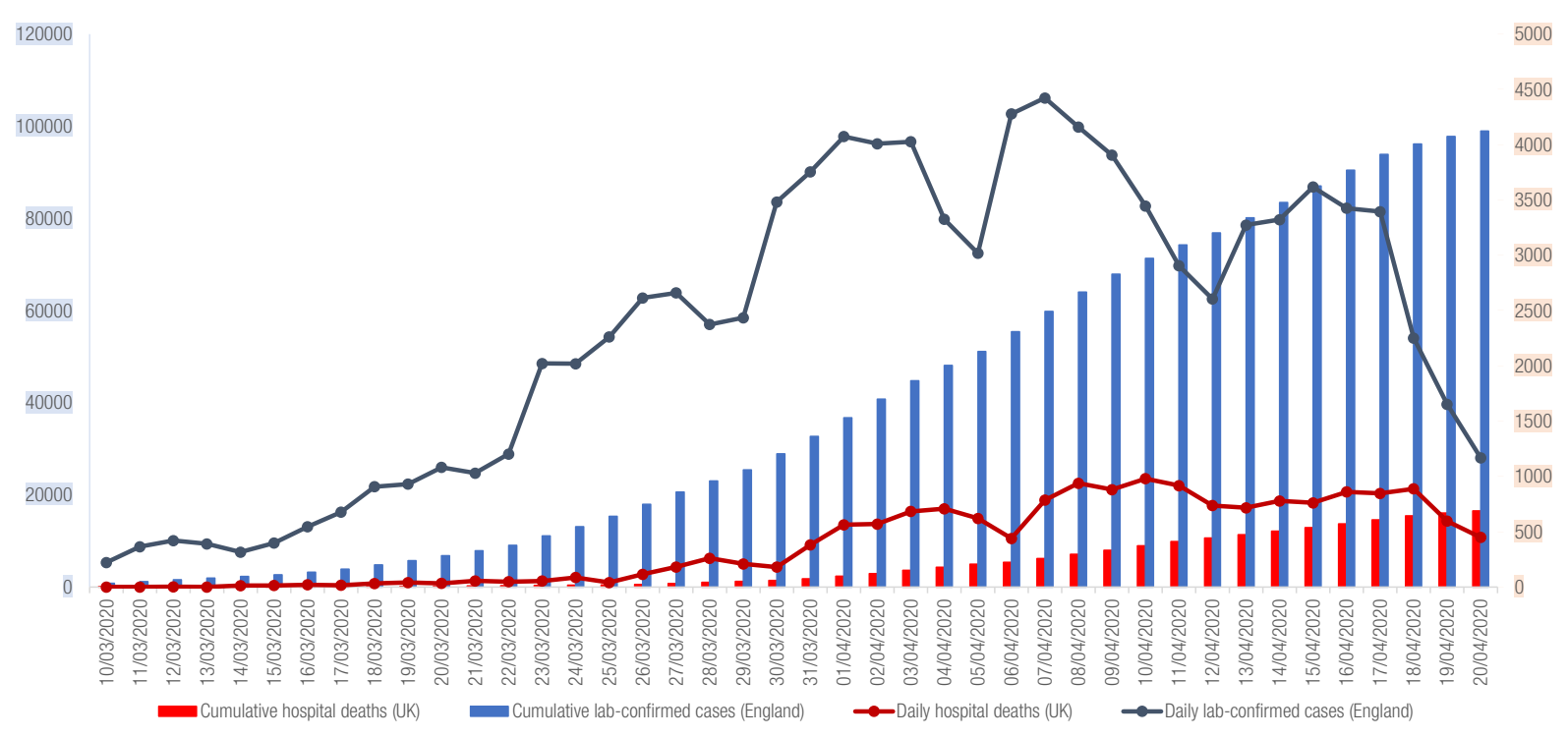

Source: Elaborated by the authors based on NHS (UK) data. 
As it is possible to see in the Figure 1, the coordination and cooperation in UKintensified on March. The "pre-first case period" on January and the "Developing prevention measures period on February" were about to avoid imported cases and to develop actions in case of community transmission. On March, the coordination activities intensified, the UK had the first identified death by COVID-19 and the actions against the spreadining of the disease became central in the governmental agenda with the Prime Minister Boris Johnson leading the Cabinet Office Briefing Room (COBRA) meetings from the beggning of the month. The lockdown was extended in April $16^{\text {th }}$. The social distance measures started to be eased on June $1^{\text {st }}$. The Figure 1 focus on the beggining of the pandemic due the revelance to understand how the United Kingdom's government organized the policy response to the COVID-19 spreadining.

\subsection{First period: pre-first case}

On January $21^{\text {st }}$, the World Health Organization published the first Situation Report about Novel Coronavirus (2019-nCoV). One day after, the British Government started monitoring direct flights from Wuhan to the UK. The Port Health team, responsible for health at UK arrival ports and airports, including a port medical inspector, port health doctor, administrative support and a team leader monitored visitors from Wuhan, was oriented to assist in case travellers feel unwell (Aamodt, 2018; Woods \& Bowman, 2018). It is the first Primary Health Care measure adopted by the UK in the outbreak.

The critical government structure to understand the coordination and cooperation process in the United Kingdom in crisis and emergencies is the Cabinet Office Briefing Room (COBRA) Emergency Committee, combining different government levels (Woods \& Bowman, 2018). In this Coronavirus outbreak, the COBRA had the first meeting on January $24^{\text {th }}$ with the presence and cooperation of emergency service leaders, senior ministers and Chief Medical Officers (CMO) from all the international, national and local territories (Aamodt, 2018; Fathalikhani et al., 2020; Hämäläinen et al., 2016). In this meeting, the government decided to try and test measures to respond to dealing with potentially infected travellers and a public health hub was established at Heathrow Airport. Until that moment, the UK had no confirmed cases and the action was concentrated in identifying and isolating possible imported cases.

Depending on the issue and the relevance level, different government actors from diverse levels attend the COBRA meetings (Lidén et al., 2015). Prime Minister Boris Johnson, as showed in Figure 2, is the Coronavirus COBRA meetings leader. He started to chair all the COVID-19 COBRA Meetings from March $2^{\text {nd }}$ leading government in the action plan to face the outbreak. 


\section{FIGURE 2 SUMMARY OF THE COORDINATION AND COOPERATION IN UK COVID-19}

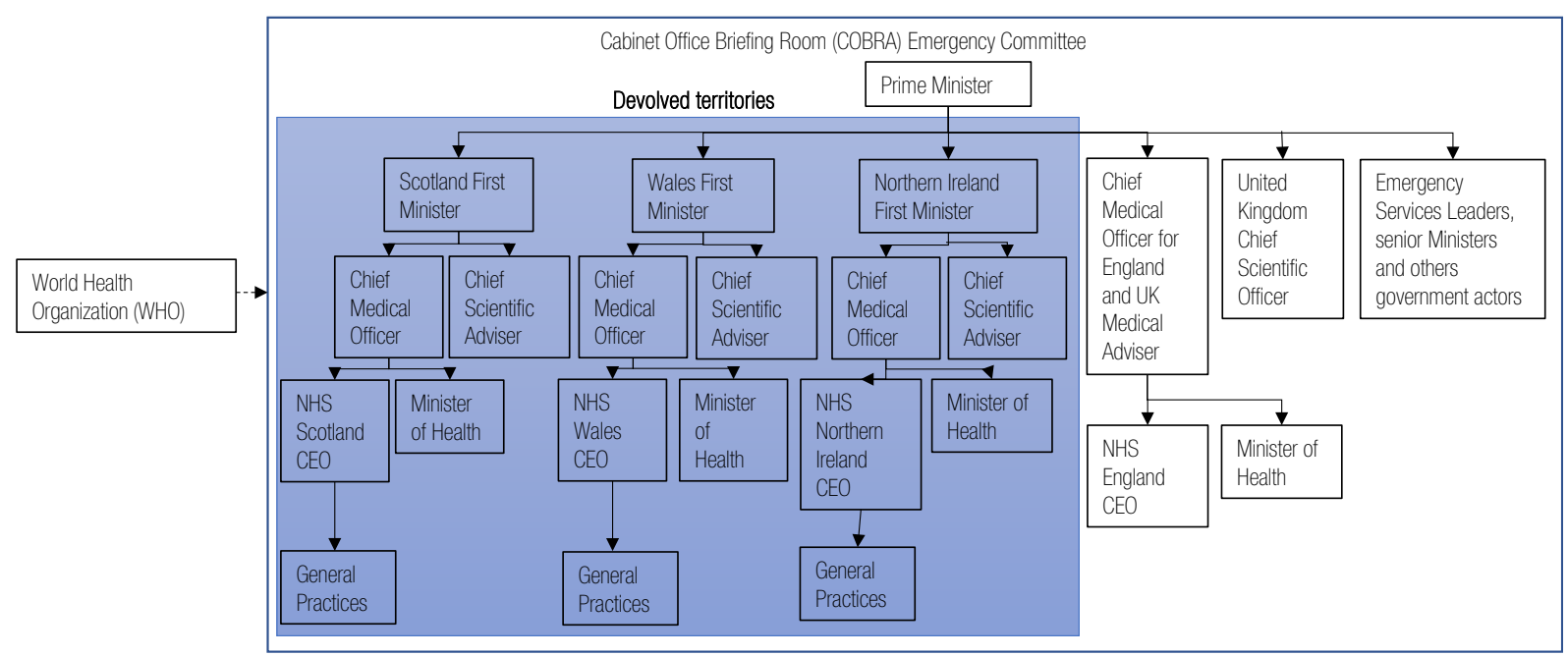

Source: Research Data.

Leaders from all devolved territories (Northern Ireland, Scotland and Wales) attend COBRA meetings. Despite previous differences in other essential political matters, such as BREXIT, the devolved nations (Scotland, Wales and Northern Ireland) decided to coordinate efforts with the central government decision-making processes during the Coronavirus outbreak (Aamodt, 2018; Fathalikhani et al., 2020). The Chief Medical Officers and Ministries of Health are managing the National Health Systems according to COBRA (Cooperation organisation) decisions and World Health Organization (international organisation) guidance (Hämäläinen et al., 2016; Lidén et al., 2015). The Chief Scientific Advisers work in cooperation with scientists and experts across (national) and out (international) the UK to offer advises evidence-based and to organise research efforts about COVID-19 (Egger, 2017; Gänzle et al., 2019).

The Coronavirus made UK government work on two battlefronts: Primary Health Care (PHC) focusing on the prevention and High Complex Cases and on curing people with COVID-19 in hospitals. It is essential to highlight that the PHC is the philosophical stone of all battle plans and all measures adopted in the UK to face COVID-19. This first period was about putting international and national organisations together to develop and apply the early strategies (Aamodt, 2018; Hämäläinen et al., 2016).

\subsection{Second period: developing prevention measures}

In this second period (February $1^{\text {st }}$ until February 29), we observed government actions in terms of regulation, guidance, research incentives and designing an action plan to avoid the spread of disease. Any suspected cases have been initially identified by general practice (local level). On February $3^{\text {rd }}$, the British government pledged 20 million pounds to develop a new vaccine for coronavirus.

The Health Protection (Coronavirus) Regulations 2020 were introduced on February $10^{\text {th }}$ with immediate effect to impose restrictions on any individual considered by health professionals to be at risk of spreading the virus. 
On February 26, the Secretary of State for Health and Social Care, Matt Hancock, updated Parliament on the government's response to coronavirus presenting a 4-part plan: Contain. Delay. Research and Mitigate, which means an alliance among the different national levels (Giljević \& Lalić Novak, 2018; Westerink et al., 2017). The research phase is happening alongside the other stages. In the same day, a new surveillance system to detect cases of COVID-19 in England was established by Public Health England (PHE) and the NHS to strengthen existing policies and to prepare for and prevent more extensive transmission of the virus. The second period starts the process of achieving high and fast cooperation and coordination between the national and subnational stance (Aamodt, 2018; Lavenex, 2009).

\subsection{Third period: first action plan}

The third phase (March $1^{\text {st }}$-March 23), the UK risk level increased and the government preparation to respond to the outbreak intensified. The Contain phase was about detecting new cases and preventing the disease spreading, while the Delay was about slowing the spread, lowering the peak and delaying cases beyond the winter season to avoid compromising NHS hospital services, requiring a quick and robust connection over all the structures (Woods \& Bowman, 2018). The research phase includes all efforts to understand the coronavirus, innovation in terms of diagnosis, production of vaccines and testing drugs already used to treat other diseases (England, 2020). Finally, "mitigate" is about providing care for people who become ill, support hospitals and act to minimise the impacts of the disease in population health, community life and economy (Department of Health and Social Care, 2020).

The Coronavirus Action Plan sets out national and local responsibilities to respond to the outbreak (Hämäläinen et al., 2016; Lidén et al., 2015). At the national level, there is national UK and and the Dept of Health and Social Care (DHSC) is primarily England as there are four NHS services in the UK. The DHSC is the lead UK Government Department with responsibility for responding to the risk posed by the pandemic (Gänzle et al., 2019).

While the four UK CMOs provide public health advice to the whole system and government, the Scientific Advisory Group for Emergencies (SAGE) is responsible for ensuring that a single source of coordinated scientific information is provided to decision-makers in COBRA (Department of Health and Social Care, 2020; Westerink et al., 2017). The subnational level seems to be relevant in the government action plan with the NHS working in partnership with Local Resilience Forums on pandemic preparedness and response delivery in healthcare systems in England and Wales (Department of Health and Social Care, 2020; Gänzle et al., 2019).

During this period, significant changes were instituted in general practice (local standard) with most surgeries shifting their consultations to telephone and video methods (WHO, 2018). Exercises also experienced growing staff issues due to the lack of testing for COVID-19 of practice staff and their immediate families with many staff members self-isolating, if they had the virus. Practices were also concerned that they were not receiving supplies.

On March $5^{\text {th, }}$ the first death of a patient with COVID-19 was registered. The government intensified advertising campaigns about the importance of hygiene and handwashing for more than 20 seconds. On March 12, the government announced moving out of containing phase into the delay phase, giving the first signs of the lockdown that was being prepared. Hence, the third period shows 
an intensification of the local level actions following the national orientations (Lidén et al., 2015). Although poorly coordinated in England.

\subsection{Fourth period: lockdown}

The United Kingdom changed the strategy to coordinate the health actions response against the coronavirus. The new plan is "Suppress-Shield-Treat-Palliate" (Horton, 2020). The British Prime Minister announced on March 24th, a lockdown with restrictions to the citizens' circulation as a measure of social isolation following the recommendations of the World Health Organization (WHO, 2020).

The Coronavirus ACT 2020 enacted on March 25, 2020, modified several health laws and regulations across the UK with an integrational approach over the government levels, for example, emergency registration of nurses and other health care professionals, emergency arrangements concerning medical practitioners (Wales and Scotland) and, compensation for emergency volunteers (Aamodt, 2018; Gänzle et al., 2019; Westerink et al., 2017).

The National Institute for Health and Care Excellence (NICE) published on April $3^{\text {rd }}$, a fast guidance on managing COVID-19 in primary care. This guide includes recommendations about how to manage the symptoms and specific advice about pneumonia (NICE, 2020). In early April a British Medical Association poll found that $61 \%$ of GPs reported that they were unable to get tests and of the $500 \mathrm{GP}$ respondents to the survey the majority said they did feel safely protected from coronavirus infection in their place of work with only $2 \%$ feeling fully protected (Bostock, 2020). During April, groups of practices started to establish particular COVID hot sites for face-to-face contact with patients with suspected COVID to triage these patients away from practices. However, the main triage approach was via the NHS help and information service NHS 111, which anyone with COVID-19 like symptoms was asked to call first.

In this period, the PHC strategy to combat COVID-19 in aligned with all the NGO (WHO), national (UK plus countries) and subnational levels (general practices), conducted by the integrated cabinet COBRA (Aamodt, 2018; Lidén et al., 2015). Also, it's visible the cooperation among the non-health institutions to support their services, since the local government workforce to supervise the social isolation, $18^{\text {th }}$ April statement, until the Foreign Secretary, $14^{\text {th }}$ April, to manage the international relationships (Aamodt, 2018; Lidén et al., 2015).

\section{FINAL CONSIDERATIONS}

The Coronavirus Disease outbreak is doing the British government work in two directions in terms of decision-making in public health: preventing the disease spreading and treating ill people. However, to avoid the health system collapse, most of the measures are focused on significant changes in Primary Health Care. The core reliance on using NHS 11 for the first contact alongside general practice, a shift to using remote consultations and the establishment of GP COVID hubs for a face-to-face meeting. There are also concerns that the substantial reductions in referrals for usual care may be storing up health care problems and many GPs are worried about delayed care and a surge in demand for attention when the first wave of this pandemic is over. 
Cooperation and coordination among the national level (UK + countries) with the subnational level (general practices and mayors) (Aamodt, 2018; Fathalikhani et al., 2020; Lavenex, 2009; Lidén et al., 2015) is one of the critical issues to understand how the British government is acting in the health crisis. This process was guided by a non-governmental organisational (NGO), World Health organisation, through your diary situation health reports (Gänzle et al., 2019), followed by the national and subnational stances (Woods \& Bowman, 2018).

The COBRA cabinet in the UK is leading and coordinating all the actions against the COVID-19 which has worked in an integrated form with all the national and subnational spheres (Aamodt, 2018; Lidén et al., 2015; Woods \& Bowman, 2018). Therefore, the UK's health case demonstrates the importance of delivering social policies through a new governance structure, as COBRA, with a high intensity of cooperation and coordination (Giljević \& Lalić Novak, 2018; Hämäläinen et al., 2016; WHO, 2020; Woods \& Bowman, 2018). While co-ordination during this period was good, actual delivery was poor both in terms of political leadership and the ability to run things centrally.

Although it has a high level of coordination between the nations, the United Kingdom was widely criticised by the other European countries for having delayed the decision to adopt strict measures of social isolation. Unfortunately, at the beginning of May, the UK is the second in the number of deaths in the World (Johns Hopkins University, 2020).

Among the limitations of this research is the focus only on health measures. Then, we suggest studies analysing the other standards and guidelines adopted by the UK government to avoid the deep of social inequalities, protect the economy and also the cooperation between the private sector and the government in this challenging moment of the humanity. 


\section{REFERENCES}

Aamodt, S. (2018). The Ability to Influence: A Comparative Analysis of the Role of Advocacy Coalitions in Brazilian Climate Politics. Review of Policy Research, 35(3), 372-397. Retrieved from https://doi.org/10.1111/ropr.12282

Baird, B., Charles, A., Honeyman, M., Maguire, D., \& Das, P. (2016). Understanding pressures in general practice. London, UK: King's Fund.

Bostock, N. (2020, April 7). Just 2\% of GPs feel fully protected against COVID-19, BMA poll shows. GP Magazine. Retrieved from https://www.gponline. com/just-2-gps-feel-fully-protected-against-covid19-bma-poll-shows/article/1679581

Chen, N., Zhou, M., Dong, X., Qu, J., Gong, F., Han, Y., ... Yu, T. (2020). Epidemiological and clinical characteristics of 99 cases of 2019 novel coronavirus pneumonia in Wuhan, China: a descriptive study. The Lancet, 395(10223), 507-513.

Egger, C. (2017). Just part-time lovers? Competition, coercive coordination, and friendship among international INGOs. Cambridge Review of International Affairs, 30(4), 394-414. Retrieved from https://doi.org/10.1080/09557571.2017.1422481

Department of Health and Social Care. (2020). Coronavirus: action plan. A guide to what you can expect across the UK. Retrieved from https://assets. publishing.service.gov.uk/government/uploads/ system/uploads/attachment_data/file/869827/ Coronavirus_action_plan_-_a_guide_to_what_ you_can_expect_across_the_UK.pdf

Fathalikhani, S., Hafezalkotob, A., \& Soltani, R. (2020, March). Government intervention on cooperation, competition, and coopetition of humanitarian supply chains. Socio-Economic Planning Sciences, 69, 100715. Retrieved from https://doi.org/10.1016/j. seps.2019.05.006

Fletcher, E., Abel, G. A., Anderson, R., Richards, S. H., Salisbury, C., Gerard Dean, S., ... Campbell, J. L. (2017). Quitting patient care and career break intentions among general practitioners in South West England: findings of a census survey of general practitioners BMJ Open, 7(4), e015853. Retrieved from https://doi.org/10.1136/bmjopen-2017-015853

Gänzle, S., Stead, D., Sielker, F., \& Chilla, T. (2019). Macro-regional Strategies, Cohesion Policy and
Regional Cooperation in the European Union: Towards a Research Agenda. Political Studies Review, 17(2), 161-174. Retrieved from https://doi. org/10.1177/1478929918781982

Giljević, T., \& Lalić Novak, G. (2018). Coordination Instruments in Croatian Integration Policy. Hrvatska i Komparativna Javna Uprava, 18(3), 373-396. Retrieved from https://doi.org/10.31297/hkju.18.3.1

Hämäläinen, R. M., Aro, A. R., Lau, C. J., Rus, D., Cori, L., \& Syed, A. M. (2016). Cross-sector cooperation in health-enhancing physical activity policymaking: More potential than achievements? Health Research Policy and Systems, 14(1), 1-12. Retrieved from https://doi.org/10.1186/s12961016-0103-6

Horton, R. (2020, March 28). Offline: COVID-19 and the NHS - "a national scandal". The Lancet, 395(10229), 1022.

Johns Hopkins University. (2020). Coronavirus COVID-19 Global Cases by the Center for Systems Science and Engineering (CSEE) at Johns Hopkins University. Retrieved from https://coronavirus.jhu. edu/map.html

Lavenex, S. (2009). Switzerland in the European research area: Integration without legislation. Swiss Political Science Review, 15(4), 629-651. Retrieved from https://doi.org/10.1002/j.1662-6370.2009. tb00148.x

Lidén, G., Nyhlén, J., \& Nyhlén, S. (2015). Forced cooperation from above: the case of Sweden's establishment reform. Policy Studies, 36(5), 468-486. Retrieved from https://doi.org/10.1080/01442872.2 015.1089983

National Institute for Health and Care Excellence. (2020, April 03). COVID-19 rapid guideline: managing symptoms (including at the end of life) in the Community. Retrieved from https://www.nice. org.uk/guidance/ng163/resources/covid19-rapidguideline-managing-symptoms-including-at-theend-of-life-in-the-community-pdf-66141899069893

NHS England. (2016). General Practice Forward View. Retrieved from https://www.england.nhs.uk/ wp-content/uploads/2016/04/gpfv.pdf

NHS Workforce Statistics. (2020, June 25). NHS Workforce March 2020 (FTE). Retrieved from https://files.digital.nhs.uk/F3/CC9E98/NHS\%20 
Workforce $\% 20$ Statistics $\% 2$ C $\% 20$ March $\% 20$ 2020\%20Bulletin.pdf

Phan, T. (2020, April). Novel coronavirus: From Discovery to clinical diagnostics. Infection, Genetics and Evolution, 79, 104211.

Primary Care Workforce Commission. (2017). The future of primary care. Creating teams for tomorrow. London, UK: Health Education England. Retrieved from https://www.hee.nhs.uk/sites/default/files/ documents/WES_The-future-of-primary-care.pdf

Westerink, J., Jongeneel, R., Polman, N., Prager, K., Franks, J., Dupraz, P., ... Mettepenningen, E. (2017, September). Collaborative governance arrangements to deliver spatially coordinated agri- environmental management. Land Use Policy, 69, 176-192. Retrieved from https://doi.org/10.1016/j. landusepol.2017.09.002

Woods, N. D., \& Bowman, A. O. M. (2018). Collective Action and the Evolution of Intergovernmental Cooperation. Policy Studies Journal, 46(3), 487-509. Retrieved from https://doi.org/10.1111/psj.12241

World Health Organization. (2018). Declaration of Astana. Geneva, Switzerland: Author.

World Health Organization. (2020, March 12). WHO announces COVID-19 outbreak a pandemic. Retrieved from http://www.euro.who.int/en/healthtopics/health-emergencies/coronavirus-covid-19/ news/news/2020/3/who-announces-covid-19outbreak-a-pandemic

\section{Tamiris Cristhina Resende}

https://orcid.org/0000-0002-7354-2658

Ph.D. Candidate in Business Administration at Federal University of Rio Grande do Norte and visiting researcher at the Centre for Health Services Studies (CHSS), University of Kent. E-mail: tamiriscristhina@gmail.com

\section{Marco Antonio Catussi Paschoalotto}

https://orcid.org/0000-0003-2276-8531

Ph.D. in Administration of Organizations at University of São Paulo and Lecturer at Unoeste Business School. E-mail: marcocatussi@gmail.com

\section{Stephen Peckham}

https://orcid.org/0000-0002-7002-2614

Professor Health Policy at London School of Hygiene and Tropical Medicine and Director of the Centre for Health Services Studies (CHSS), School of Social Policy, Sociology and Social Research, University of Kent. E-mail: S.peckham@kent.ac.uk

\section{Claudia Souza Passador}

https://orcid.org/0000-0002-9333-563X

Ph.D. in Education and Associate Professor at University of São Paulo. E-mail: cspassador@usp.br

\section{João Luiz Passador}

https://orcid.org/0000-0002-0460-8852

Ph.D. in Business Management at Getulio Vargas Foundation and Full Professor at University of São Paulo. E-mail: jlpassador@usp.br 